\title{
Evaluation of curcumin acetates and amino acid conjugates as proteasome inhibitors
}

\author{
SHENG BIAO WAN ${ }^{1 *}$, HUANJIE YANG ${ }^{2 *}$, ZHONGYUAN ZHOU ${ }^{1}$, QIUZHI CINDY CUI ${ }^{2}$, DI CHEN ${ }^{2}$, \\ JYOTI KANWAR ${ }^{2}$, IMTHIYAZ MOHAMMAD ${ }^{2}$, Q. PING DOU ${ }^{2}$ and TAK HANG CHAN ${ }^{1,3}$ \\ ${ }^{1}$ Department of Applied Biology and Chemical Technology and the Open Laboratory for Chiral Technology, \\ The Institute of Molecular Technology for Drug Discovery and Synthesis, The Hong Kong Polytechnic University, \\ Hung Hom, Kowloon, Hong Kong SAR, P.R. China; ${ }^{2}$ The Prevention Program, Barbara Ann Karmanos Cancer Institute, \\ and Department of Pathology, School of Medicine, Wayne State University, Detroit, MI, USA; \\ ${ }^{3}$ Department of Chemistry, McGill University, Montreal, Quebec, Canada
}

Received February 17, 2010; Accepted April 9, 2010

DOI: 10.3892/ijmm_00000484

\begin{abstract}
Curcumin (diferuloylmethane) is the main active ingredient of turmeric, a traditional herbal medicine and food of south Asia. Curcumin has been found to have a wide range of biological activities, including antioxidant, anti-inflammatory, chemopreventive and chemotherapeutic activities. Curcumin is currently being tested in clinical trials for treatment of various types of cancers, including multiple myeloma, pancreatic cancer and colon cancer. Although no toxicity associated with curcumin (even at very high doses) has been observed, the effects of curcumin in other solid tumors have been modest, primarily due to poor water solubility and poor bioavailability in tissues remote from the gastrointestinal tract. Therefore, there is a need for the discovery of curcumin analogs with better water solubility or greater bioavailability for the treatment of solid tumors such as prostate cancer. In this study, curcumin acetates and amino acid conjugates of curcumin were studied in terms of their proteasome inhibitory and antiproliferative effects against several human cancer cell lines. It was found that the water soluble amino acid conjugates of curcumin showed a potent antiproliferative effect and are potent proteasome inhibitors. Docking studies of the
\end{abstract}

Correspondence to: Professor Tak Hang Chan, Department of Applied Biology and Chemical Technology and the Open Laboratory for Chiral Technology, The Institute of Molecular Technology for Drug Discovery and Synthesis, The Hong Kong Polytechnic University, Hung Hom, Kowloon, Hong Kong SAR, P.R. China

Dr Q. Ping Dou, The Prevention Program, Barbara Ann Karmanos Cancer Institute, and Department of Pathology, School of Medicine, Wayne State University, Detroit, MI, USA

E-mail: bcchanth@polyu.edu.hk; doup@karmanos.org

*Contributed equally

Key words: curcumin, proteasome inhibitor, cytotoxicity curcumin amino acid conjugates for proteasome inhibition were carried out to explain their biological activities. It is suggested that they may serve as the water soluble analogs of curcumin.

\section{Introduction}

Curcumin (diferuloylmethane, $\mathbf{1}$ ) is the main active ingredient of turmeric, which has been used as a traditional herbal medicine and food in south Asia for centuries (1) Curcumin has been found to have a wide range of biological activities, including antioxidant, anti-inflammatory, chemopreventive and chemotherapeutic activities (2). The benefit and chemopreventative role of dietary curcumin have been observed in a variety of rodent tumor models (2-4). Curcumin is currently being tested in clinical trials for the treatment of various types of cancers, including multiple myeloma, pancreatic cancer and colon cancer (2-4). Although no toxicity associated with curcumin (even at very high doses) has been observed (2-4), the effects of curcumin in other solid tumors have been modest, primarily due to poor water solubility and poor bioavailability in tissues remote from the gastrointestinal tract (5). It has also been shown that curcumin undergoes extensive metabolic transformations in the gastrointestinal tract $(6,7)$. Therefore, there is a need for the discovery of curcumin analogs with better water solubility or greater bioavailability for the treatment of solid tumors such as prostate cancer.

Recently, it has been reported that the tumor cellular proteasome is an important target of curcumin (8). The ubiquitin-proteasome pathway plays a central role in the degradation of proteins involved in several pathways including the cell cycle, cellular proliferation and apoptosis (9). Studies have shown that the treatment with proteasome inhibitors results in decreased proliferation, induction of apoptosis and sensitization of a variety of tumor cells to conventional chemotherapeutic agents and irradiation. The impressive effect of proteasome inhibitor bortezomib (Velcade/PS-341), a dipeptidyl boronic compound, has been shown as a single agent and in combination with other anticancer drugs for treatment of multiple myeloma and other hematological 
malignancies. However, there is much less evidence of bortezomib's efficacy versus solid tumors. Also, some toxicity was observed in the bortezomib trials (10). Therefore, there is a need to search for novel drugs and novel proteasome inhibitors with less or no toxic side effects.

Our goal was to synthesize the monoacetate and diacetate of curcumin and to ascertain whether they may serve as a prodrug of curcumin or whether they are effective proteasome inhibitors in their own right. From our previous research on tea polyphenol EGCG modification, EGCG peracetate, though inactive as a proteasome inhibitor, was found to be a prodrug of EGCG with enhanced bioactivity in proteasome inhibition (11). Secondly, the amino acid conjugates of curcumin are expected to have improved water solubility and are likely to be better absorbed than curcumin itself. Finally, a poly-(L-glutamic acid)-paclitaxel conjugate has been found to enhance the water solubility of paclitaxel and its antitumor activity (12). We aimed to prepare a polyglutamic acid conjugate of curcumin and to determine whether it exhibits more desirable activities.

\section{Materials and methods}

General. The starting materials and reagents, purchased from commercial suppliers, were used without further purification. Anhydrous methylene chloride was distilled under nitrogen from $\mathrm{CaH}_{2}$. Anhydrous DMF was distilled under vacuum from $\mathrm{CaH}_{2}$. Reaction flasks were flame-dried under a stream of $\mathrm{N}_{2}$. All moisture-sensitive reactions were conducted under a nitrogen atmosphere. Flash chromatography was carried out using silica-gel 60 (70-230 mesh). The melting points were uncorrected. ${ }^{1} \mathrm{H}-\mathrm{NMR}$ and ${ }^{13} \mathrm{C} \mathrm{NMR}(400 \mathrm{MHz})$ spectra were measured with TMS as an internal standard when $\mathrm{CDCl}_{3}$ and acetone- $d_{6}$ were used as solvent. High-resolution (ESI) MS spectra were recorded using a QTOF-2 Micromass spectrometer. The X-ray crystal structure of $\mathbf{2}$ was determined by a Brüker CCD area detector diffractometer.

Materials. Curcumin was obtained from Sigma-Aldrich (St. Louis, MO) and dissolved in ethanol (Sigma) at a stock concentration of $10 \mathrm{mM}$, aliquoted and stored at $-20^{\circ} \mathrm{C}$. Purified rabbit 20S proteasome and fluorogenic substrate Suc-LLVY-AMC for the proteasomal chymotrypsin-like (CT-like) activity were obtained from Calbiochem Inc. (San Diego, CA). Fetal bovine serum (FBS) was from Tissue Culture Biologicals (Tulare, CA). Penicillin and streptomycin were purchased from Invitrogen Co. (Carlsbad, CA). RPMI-1640 medium was purchased from Invitrogen Co. MTT (3-4,5-dimethyltriazol-2-yl-2,5-diphenyl-tetrazolium bromide) was purchased from Sigma-Aldrich. Procedures described in the literature were used for the preparation of curcumin monoacetate 5 and curcumin diacetate $\mathbf{2}$ (12).

(1E,4Z,6E)-1,7-Bis(4-acetoxy-3-methoxyphenyl)-5-hydroxyhepta-1,4,6-trien-3-one (2). ${ }^{1} \mathrm{H}-\mathrm{NMR}\left(400 \mathrm{MHz}, \mathrm{CDCl}_{3}\right) \delta$ : $16.0(1 \mathrm{H}, \mathrm{br}), 7.58(2 \mathrm{H}, \mathrm{d}, \mathrm{J}=15.8 \mathrm{~Hz}), 7.11(4 \mathrm{H}, \mathrm{m}), 7.03(2 \mathrm{H}$, $\mathrm{d}, J=8.1 \mathrm{~Hz}), 6.54(2 \mathrm{H}, \mathrm{d}, \mathrm{J}=15.8 \mathrm{~Hz}), 5.81(1 \mathrm{H}, \mathrm{s}), 3.82$

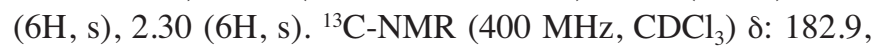
168.6, 151.1, 141.0, 139.6, 133.7, 124.0, 123.0, 120.8, 111.2, $101.6,55.6,20.4$.
(1E,4Z,6E)-1-[4'-(tert-Butyldimethylsilyloxy)-3'-methoxyphenyl]-5-hydroxy-7-(4"-hydroxy-3"-methoxyphenyl)hepta1,4,6-trien-3-one (3). ${ }^{1} \mathrm{H}-\mathrm{NMR}\left(400 \mathrm{MHz}, \mathrm{CDCl}_{3}\right)$ 8: 16.0 (1H, br), $7.44(2 \mathrm{H}, \mathrm{d}, J=15.8 \mathrm{~Hz}), 6.91(4 \mathrm{H}, \mathrm{m}), 6.77(1 \mathrm{H}, \mathrm{d}$, $J=8.0 \mathrm{~Hz}), 6.70(1 \mathrm{H}, \mathrm{d}, J=8.0 \mathrm{~Hz}), 6.35(2 \mathrm{H}, \mathrm{dd}, J=6.0$, $15.8 \mathrm{~Hz}), 5.66(1 \mathrm{H}, \mathrm{s}), 3.70(3 \mathrm{H}, \mathrm{s}), 3.68(3 \mathrm{H}, \mathrm{s}), 0.87(9 \mathrm{H}, \mathrm{s})$, $0.05(6 \mathrm{H}, \mathrm{s}) .{ }^{13} \mathrm{C}-\mathrm{NMR}\left(400 \mathrm{MHz}, \mathrm{CDCl}_{3}\right) \delta_{\mathrm{C}}: 183.9,183.6$, 151.6, 148.5, 147.9, 147.4, 141.2, 141.0, 129.4, 128.0, 123.3, $122.6,122.5,122.1,115.4,111.6,110.2,101.8,56.3,55.8$, $26.1,18.9,-4.0$.

(1E,4Z,6E)-7-(4"-Acetoxy-3"-methoxyphenyl)-5-hydroxy-1[4'-(tert-butyldimethylsilyloxy)-3'-methoxyphenyl]hepta1,4,6-trien-3-one (4). ${ }^{1} \mathrm{H}-\mathrm{NMR}\left(400 \mathrm{MHz} \mathrm{CDCl}_{3}\right.$ ) 8: 16.0 (1H, br), $7.62(2 \mathrm{H}, \mathrm{dd}, J=4.0,15.8 \mathrm{~Hz}), 7.14(4 \mathrm{H}, \mathrm{m}), 6.87$ $(2 \mathrm{H}, \mathrm{d}, J=8.0 \mathrm{~Hz}), 6.57(1 \mathrm{H}, \mathrm{dd}, J=1.6 \mathrm{~Hz}), 6.53(1 \mathrm{H}, \mathrm{dd}$, $J=1.6 \mathrm{~Hz}), 5.84(1 \mathrm{H}, \mathrm{s}), 3.88(3 \mathrm{H}, \mathrm{s}), 3.86(3 \mathrm{H}, \mathrm{s}), 2.34(3 \mathrm{H}$, s), $1.00(9 \mathrm{H}, \mathrm{s}), 0.18(6 \mathrm{H}, \mathrm{s}) .{ }^{13} \mathrm{C}-\mathrm{NMR}\left(400 \mathrm{MHz}, \mathrm{CDCl}_{3}\right)$ $\delta_{\mathrm{C}}: 184.9,182.4,169.3,151.8,151.7,148.1,141.6,139.8$, $134.5,129.3,124.7,123.7,122.7,122.5,121.6,121.4,111.8$, $111.5,102.0,56.4,55.9,26.1,21.1,18.9,-4.0$.

(1E,4Z,6E)-7-(4"-Acetoxy-3"-methoxyphenyl)-5-hydroxy-1(4'-hydroxy-3'-methoxyphenyl)hepta-1,4,6-trien-3-one (5). ${ }^{1} \mathrm{H}-\mathrm{NMR}\left(400 \mathrm{MHz}, \mathrm{CDCl}_{3}\right)$ \&: $16.0(1 \mathrm{H}, \mathrm{br}), 7.60(2 \mathrm{H}, \mathrm{dd}$, $J=8.1,15.8 \mathrm{~Hz}), 7.12(4 \mathrm{H}, \mathrm{m}), 6.91(1 \mathrm{H}, \mathrm{d}, \mathrm{J}=8.1 \mathrm{~Hz}), 6.53$ $(1 \mathrm{H}, \mathrm{d}, \mathrm{J}=15.8 \mathrm{~Hz}), 6.48(1 \mathrm{H}, \mathrm{d}, \mathrm{J}=15.8 \mathrm{~Hz}), 5.84(1 \mathrm{H}, \mathrm{s})$, $3.89(3 \mathrm{H}, \mathrm{s}), 3.85(3 \mathrm{H}, \mathrm{s}), 2.32(3 \mathrm{H}, \mathrm{s}) .{ }^{13} \mathrm{C}-\mathrm{NMR}(400 \mathrm{MHz}$, $\left.\mathrm{CDCl}_{3}\right) \delta_{\mathrm{C}}: 184.4,181.6,168.8,151.2,147.9,146.8,141.0$, 139.2, 133.9, 127.3, 124.0, 123.1, 122.9, 121.5, 120.8, 114.8, $111.3,109.6,101.4,55.7,31.4,22.5,20.5,14.0$.

(1E,6E)-1,7-Bis(4-N-tert-butoxycarbonylglycinoyl-3methoxyphenyl)hepta-1,6-diene-3,5-dione (6). Under an $\mathrm{N}_{2}$ atmosphere, a solution of curcumin $(368 \mathrm{mg}, 1 \mathrm{mmol})$ and $\mathrm{N}$ boc-glycine $(438 \mathrm{mg}, 2.5 \mathrm{mmol})$ in anhydrous $\mathrm{CH}_{2} \mathrm{Cl}_{2}(50 \mathrm{ml})$ was treated with EDCI (573 mg, $3 \mathrm{mmol}$ ) and DMAP (366 mg, $3 \mathrm{mmol}$ ) at room temperature. The reaction mixture was stirred overnight. Saturated aqueous $\mathrm{NaHCO}_{3}$ solution was added. The organic phase was separated, and the aqueous layer was extracted with $\mathrm{CH}_{2} \mathrm{Cl}_{2}$. The organic phases were combined and dried with anhydrous $\mathrm{Na}_{2} \mathrm{SO}_{4}$. After evaporation of the solvent, the residue was purified by column chromatography on silica gel (EtOAc/n-hexane), and the product was recrystallized in $\mathrm{MeOH}$ and acetonitrile to afford compound 6 (550 mg, 81\% yield): mp 64-66 ${ }^{\circ} \mathrm{C} ;{ }^{1} \mathrm{H}-\mathrm{NMR}(400 \mathrm{MHz}$, $\left.\mathrm{CDCl}_{3}\right)$ \&: $15.86(1 \mathrm{H}, \mathrm{bs}), 7.58(2 \mathrm{H}, \mathrm{d}, \mathrm{J}=15.8 \mathrm{~Hz}), 7.11(6 \mathrm{H}$, m), $6.55(2 \mathrm{H}, \mathrm{d}, \mathrm{J}=15.8 \mathrm{~Hz}), 5.82(1 \mathrm{H}, \mathrm{S}), 5.22$ (2H, bs), 4.20 (4 H, d, J=4.8 Hz), $3.81(6 \mathrm{H}, \mathrm{s}), 1.45(18 \mathrm{H}, \mathrm{s}) ;{ }^{13} \mathrm{C}-\mathrm{NMR}$ $\left(400 \mathrm{MHz}, \mathrm{CDCl}_{3}\right) \delta_{\mathrm{C}}: 183.5,169.0,156.2,151.6,141.6$, 140.4, 134.6, 124.8, 123.9, 122.0, 112.4, 102.3, 80.9, 56.4, 42.7, 28.9; HRMS (ESI) calcd for $\mathrm{C}_{35} \mathrm{H}_{42} \mathrm{~N}_{2} \mathrm{O}_{12}$ (M) 682.2738, found 682.2722 .

Compounds 7, 8, and 9 were synthesized with the same synthetic procedure as compound $\mathbf{6}$.

(1E,6E)-1,7-Bis(4-N-tert-butoxycarbonylalaninoyl-3methoxyphenyl)hepta-1,6-diene-3,5-dione (7). The title compound was obtained after recrystallization (in EtOAc/ 
hexane) in $90 \%$ yield as a yellow solid: $\mathrm{mp} 120-122^{\circ} \mathrm{C}$; ${ }^{1} \mathrm{H}-\mathrm{NMR}\left(400 \mathrm{MHz}, \mathrm{CDCl}_{3}\right)$ $\delta: 15.85(1 \mathrm{H}, \mathrm{bs}), 7.63(2 \mathrm{H}, \mathrm{d}$, $\mathrm{J}=15.7 \mathrm{~Hz}), 7.17(6 \mathrm{H}, \mathrm{m}), 6.59(2 \mathrm{H}, \mathrm{d}, \mathrm{J}=15.7 \mathrm{~Hz}), 5.86(1 \mathrm{H}$, bs), $5.14(2 \mathrm{H}, \mathrm{d}, \mathrm{J}=7.2 \mathrm{~Hz}), 4.62(2 \mathrm{H}, \mathrm{m}), 3.85(6 \mathrm{H}, \mathrm{s}), 1.59$ $(4 \mathrm{H}, \mathrm{d}, \mathrm{J}=7.2 \mathrm{~Hz}), 1.47(18 \mathrm{H}, \mathrm{s}) ;{ }^{13} \mathrm{C}-\mathrm{NMR}\left(400 \mathrm{MHz}, \mathrm{CDCl}_{3}\right)$ $\delta_{\mathrm{C}}: 183.7,172.1,155.8,151.9,141.7,140.6,134.8,125.0,123.8$, 121.7, 112.2, 102.5, 96.8, 80.7, 56.6, 50.0, 29.0, 19.4; HRMS (ESI) calcd for $\mathrm{C}_{37} \mathrm{H}_{46} \mathrm{~N}_{2} \mathrm{O}_{12} \mathrm{Na}(\mathrm{M}+\mathrm{Na}) 733.2948$, found 733.2938 .

(1E,6E)-1,7-Bis(4-N-tert-butoxycarbonylvalinoyl-3-methoxyphenyl)hepta-1,6-diene-3,5-dione (8). The title compound was obtained after recrystallization (in EtOAc/ hexane) in $92 \% \%$ yield as a yellow solid: $\mathrm{mp} 187-189^{\circ} \mathrm{C}$; ${ }^{1} \mathrm{H}-\mathrm{NMR}$ $\left(400 \mathrm{MHz}, \mathrm{CDCl}_{3}\right) \delta: 15.88(1 \mathrm{H}, \mathrm{s}), 7.61(2 \mathrm{H}, \mathrm{d}, \mathrm{J}=15.7 \mathrm{~Hz})$, $7.15(6 \mathrm{H}, \mathrm{m}), 6.58(2 \mathrm{H}, \mathrm{d}, \mathrm{J}=15.7 \mathrm{~Hz}), 5.82(1 \mathrm{H}, \mathrm{s}), 5.14$ $(2 \mathrm{H}, \mathrm{d}, \mathrm{J}=8.9 \mathrm{~Hz}), 4.54(2 \mathrm{H}, \mathrm{m}), 3.83(6 \mathrm{H}, \mathrm{s}), 2.41(2 \mathrm{H}, \mathrm{m})$, $1.46(18 \mathrm{H}, \mathrm{s}), 1.10(6 \mathrm{H}, \mathrm{d}, \mathrm{J}=6.8 \mathrm{~Hz}), 1.04(6 \mathrm{H}, \mathrm{d}, \mathrm{J}=6.8 \mathrm{~Hz})$; ${ }^{13} \mathrm{C}-\mathrm{NMR}\left(400 \mathrm{MHz}, \mathrm{CDCl}_{3}\right) \delta_{\mathrm{C}}: 183.5,170.8,155.7,151.7$, 134.6, 124.8, 123.7, 121.5, 112.8, 102.6, 80.4, 59.0, 56.1, 31.7, $28.8,19.5,17.6$; HRMS (ESI) calcd for $\mathrm{C}_{41} \mathrm{H}_{54} \mathrm{~N}_{2} \mathrm{O}_{12} \mathrm{Na}$ $(\mathrm{M}+\mathrm{Na}) 789.3574$, found 789.3558 .

(1E,6E)-1,7-Bis(4-N-tert-butoxycarbonylglutamoyl-3methoxyphenyl)hepta-1,6-diene-3,5-dione, 5'-tert-butyl ester (9). The title compound was obtained in $80 \%$ yield as a yellow solid: mp 70-72 ${ }^{\circ} \mathrm{C} ;{ }^{1} \mathrm{H}-\mathrm{NMR}\left(400 \mathrm{MHz}, \mathrm{CDCl}_{3}\right)$ $\delta: 15.84$ $(1 \mathrm{H}, \mathrm{bs}), 7.61(2 \mathrm{H}, \mathrm{d}, \mathrm{J}=15.8 \mathrm{~Hz}), 7.14(6 \mathrm{H}, \mathrm{m}), 6.56(2 \mathrm{H}, \mathrm{d}$, $\mathrm{J}=15.8 \mathrm{~Hz}), 5.84(1 \mathrm{H}, \mathrm{s}), 5.20(2 \mathrm{H}, \mathrm{d}, \mathrm{J}=3.8 \mathrm{~Hz}), 4.26(2 \mathrm{H}$, $\mathrm{m}), 3.85(6 \mathrm{H}, \mathrm{s}), 2.73(4 \mathrm{H}, \mathrm{m}), 2.28(2 \mathrm{H}, \mathrm{m}), 2.05(2 \mathrm{H}, \mathrm{m})$, $1.48(18 \mathrm{H}, \mathrm{s}), 1.46(18 \mathrm{H}, \mathrm{s}) ;{ }^{13} \mathrm{C}-\mathrm{NMR}\left(400 \mathrm{MHz}, \mathrm{CDCl}_{3}\right)$ $\delta_{\mathrm{C}}: 189.0,174.0,171.7,171.2,170.8,155.9,151.8,141.7$, $140.4,134.1,124.7,123.7,121.9,112.1,102.2,83.7,82.7$, $80.3,60.0,56.4,53.8,31.5,30.6,28.8,28.6,28.4,28.3,28.2$, 28.1, 22.1; HRMS (ESI) calcd for $\mathrm{C}_{49} \mathrm{H}_{66} \mathrm{~N}_{2} \mathrm{O}_{16} \mathrm{Na}(\mathrm{M}+\mathrm{Na})$ 961.4310, found 961.4218 .

(1E,6E)-1,7-Bis(4-glycinoyl-3-methoxyphenyl)hepta-1,6diene-3,5-dione hydrochloride (10). Under an $\mathrm{N}_{2}$ atmosphere, compound 6 (340 mg, $0.5 \mathrm{mmol}$ ) was dissolved in anhydrous $\mathrm{CH}_{2} \mathrm{Cl}_{2}(30 \mathrm{ml})$ and treated with TFA at $-5-0^{\circ} \mathrm{C}$. After the reaction mixture was stirred for $5 \mathrm{~h}$ at $-5-0^{\circ} \mathrm{C}, 2 \mathrm{M} \mathrm{HCl}(5 \mathrm{ml})$ was added dropwise. After evaporation of the solvent under reduced pressure, the residue was recrystallized in methanol/ $\mathrm{CH}_{3} \mathrm{CN}$ to afford compound $\mathbf{1 0}$ (230 mg, 83\% yield): $\mathrm{mp}$ $126-128^{\circ} \mathrm{C}$; ${ }^{1} \mathrm{H}-\mathrm{NMR}\left(400 \mathrm{MHz}, \mathrm{CD}_{3} \mathrm{OD}\right) \delta: 8.69$ (1H, bs), $7.67(2 \mathrm{H}, \mathrm{d}, \mathrm{J}=15.0 \mathrm{~Hz}), 7.40(2 \mathrm{H}, \mathrm{bs}), 7.28(2 \mathrm{H}, \mathrm{m}), 7.19(2 \mathrm{H}$, d, J=7.7 Hz), $6.88(2 \mathrm{H}, \mathrm{d}, \mathrm{J}=15.0 \mathrm{~Hz}), 6.09(1 \mathrm{H}, \mathrm{bs}), 4.18(4 \mathrm{H}$, s), $3.90(6 \mathrm{H}, \mathrm{s}) ;{ }^{13} \mathrm{C}-\mathrm{NMR}\left(400 \mathrm{MHz}, \mathrm{CD}_{3} \mathrm{OD}\right) \delta_{\mathrm{C}}: 183.5$, $165.9,151.7,140.7,139.8,135.4,125.1,123.0,121.3,111.5$, 55.7, 40.0; HRMS (ESI) calcd for $\mathrm{C}_{25} \mathrm{H}_{27} \mathrm{~N}_{2} \mathrm{O}_{8}(\mathrm{M}+\mathrm{H})$ 483.1767, found 483.1770.

Compounds 11 and $\mathbf{1 2}$ were obtained from their $N$-Boc precursors in the same manner as compound $\mathbf{1 0}$.

(1E,6E)-1,7-Bis(4-alaninoyl-3-methoxyphenyl)hepta-1,6diene-3,5-dione hydrochloride (11). The title compound was obtained after recrystallization (in water or methanol/ether) in $86 \%$ yield as yellow solid: $\mathrm{mp} 160-163^{\circ} \mathrm{C} ;{ }^{1} \mathrm{H}-\mathrm{NMR}$ (400 MHz, CD $3 \mathrm{OD}) \delta: 8.65(1 \mathrm{H}, \mathrm{bs}), 7.61(2 \mathrm{H}, \mathrm{bs}), 7.36$ $(6 \mathrm{H}, \mathrm{m}), 6.83(2 \mathrm{H}, \mathrm{bs}), 4.46(2 \mathrm{H}, \mathrm{m}), 3.84(6 \mathrm{H}, \mathrm{s}), 1.75(6 \mathrm{H}$, $\mathrm{d}, \mathrm{J}=7.2 \mathrm{~Hz}$ ); ${ }^{13} \mathrm{C}-\mathrm{NMR}\left(400 \mathrm{MHz}, \mathrm{CD}_{3} \mathrm{OD}\right) \delta_{\mathrm{C}}: 184.7,169.7$, $152.8,142.2,141.0,136.6,126.3,124.1,123.2,114.9,57.0$, 16.7; HRMS (ESI) calcd for $\mathrm{C}_{27} \mathrm{H}_{31} \mathrm{~N}_{2} \mathrm{O}_{8}(\mathrm{M}+\mathrm{H})$ 511.2080, found 511.2078 .

(1E,6E)-1,7-Bis(4-valinoyl-3-methoxyphenyl)hepta-1,6diene-3,5-dione hydrochloride (12). The title compound was obtained after recrystallization (in water or methanol/ether) in $84 \%$ yield as a yellow solid: $\mathrm{mp} 181-183^{\circ} \mathrm{C}$; ${ }^{1} \mathrm{H}-\mathrm{NMR}$

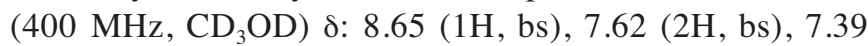
$(6 \mathrm{H}, \mathrm{m}), 6.87(2 \mathrm{H}, \mathrm{bs}), 6.11(1 \mathrm{H}, \mathrm{bs}), 4.28(2 \mathrm{H}, \mathrm{d}, \mathrm{J}=4.0 \mathrm{~Hz})$, $3.89(6 \mathrm{H}, \mathrm{s}), 2.52(2 \mathrm{H}, \mathrm{m}), 1.24(6 \mathrm{H}, \mathrm{d}, \mathrm{J}=6.0 \mathrm{~Hz}), 1.21(6 \mathrm{H}$, $\mathrm{d}, \mathrm{J}=6.0 \mathrm{~Hz}) ;{ }^{13} \mathrm{C}-\mathrm{NMR}\left(400 \mathrm{MHz}, \mathrm{CD}_{3} \mathrm{OD}\right) \delta_{\mathrm{C}}: 184.7,168.5$, $152.8,141.7,141.0,136.7,126.4,124.3,122.6,113.1,59.7$, 56.7, 31.5, 18.5; HRMS (ESI) calcd for $\mathrm{C}_{31} \mathrm{H}_{39} \mathrm{~N}_{2} \mathrm{O}_{8}(\mathrm{M}+\mathrm{H})$ 567.2706, found 567.2722.

Synthesis of curcumin-polyglutamic acid conjugate (13). Under an $\mathrm{N}_{2}$ atmosphere, polyglutamic acid sodium salt (60 mg, MW: 15000-50000) was suspended in anhydrous DMF (10 ml), and curcumin (30 mg, $0.082 \mathrm{mmol})$, EDCI (45 mg, $0.23 \mathrm{mmol}$ ) and DMAP (20 mg, $0.16 \mathrm{mmol}$ ) were added. The reaction mixture was stirred overnight. TLC indicated that all of the curcumin had reacted. DMF was evaporated under reduced pressure. The residue was dissolved in $10 \mathrm{ml}$ water and extracted with $\mathrm{CH}_{2} \mathrm{Cl}_{2}$. The water layer was concentrated by freeze drying. The residue was dissolved in methanol. $\mathrm{CH}_{2} \mathrm{Cl}_{2}$ and ether were added to precipitate the product as a yellow solid $(78 \mathrm{mg})$. Assuming that all of the curcumin had reacted, the amount of curcumin in the curcumin-polyglutamic acid conjugate was estimated to be $34 \%$ by weight using the equation in Fig. 6 .

Nucleophilic susceptibility analysis. Nucleophilic susceptibility analysis was performed by Quantum CAChe (Fujitsu; Fairfield, NJ) using the PM5 geometry and PM5 wavefunction in water. The colored 'bull's eye' with a yellow center denotes atoms that are highly susceptible for nucleophilic attack.

Computational docking. The crystal structure of the eukaryotic yeast $20 \mathrm{~S}$ proteasome used for the docking studies was obtained from the Protein Database. The yeast 20S proteasome is structurally very similar to the mammalian $20 \mathrm{~S}$ proteasome, and the chymotrypsin active site between the two species is highly conserved. The AutoDock software was run on an i386 architecture computer operating with Redhat Linux 6.0 ${ }^{\mathrm{TM}}$ operating system. The selected docking image was the cluster with the most members and the lowest binding free energy. Structural output from AutoDock was visualized using PyMOL software.

Cell cultures. Human colon cancer (HCT116 and SW480) and prostate cancer (PC-3 and LNCaP) cells were purchased from the American Type Culture Collection (Manassas, VA) and were grown in RPMI-1640 medium supplemented with 

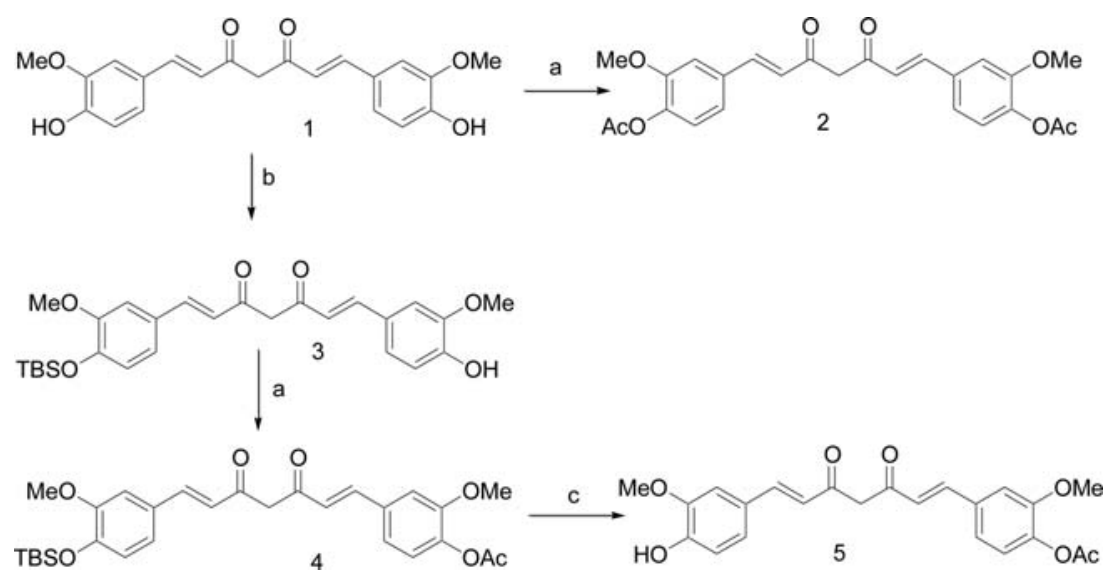

Figure 1. Synthesis of curcumin monoacetate (5) and curcumin diacetate (2): a, $\mathrm{Ac}_{2} \mathrm{O} /$ pyridine; b, TBDMSCl/imidazole/DMF; c, TBAF/THF.

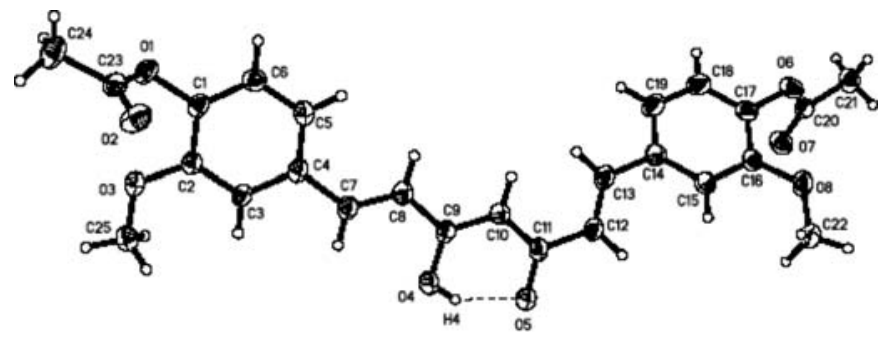

Figure 2. Molecular stereo structure of compound 2.

$10 \% \mathrm{FBS}, 100$ units $/ \mathrm{ml}$ of penicillin, and $100 \mu \mathrm{g} / \mathrm{ml}$ of streptomycin. Cells were maintained at $37^{\circ} \mathrm{C}$ in $5 \% \mathrm{CO}_{2}$.

Inhibition of purified 20 S proteasome activity by curcumin and its analogs. A purified rabbit $20 \mathrm{~S}$ proteasome (35 ng) was incubated with $20 \mu \mathrm{M}$ of substrate Suc-LLVY-AMC in $100 \mu \mathrm{l}$ assay buffer (20 mM Tris- $\mathrm{HCl}, \mathrm{pH} 7.5)$ in the presence of curcumin or curcumin analogs at different concentrations or the solvent for $2 \mathrm{~h}$ at $37^{\circ} \mathrm{C}$, followed by measurement of hydrolysis of the fluorogenic substrates using a Wallac Victor $3^{\mathrm{TM}}$ multi-label counter with $355-\mathrm{nm}$ excitation and 460-nm emission wavelengths.

Inhibition of the proteasome activity in cell extracts by curcumin and its analogs. Cell extracts from PC-3 or LNCaP cells were incubated with curcumin and its analogs for $2 \mathrm{~h}$ at $37^{\circ} \mathrm{C}$, followed by the proteasomal chymotryptic activity assay.

MTT assay. Cells were grown in a 96-well plate. Triplicate wells of cells were treated with indicated concentrations of curcumin or the curcumin analogs for $24 \mathrm{~h}$.

After aspiration of medium, MTT $(1 \mathrm{mg} / \mathrm{ml})$ was then added to the cell cultures, followed by incubation for $3 \mathrm{~h}$ at $37^{\circ} \mathrm{C}$. After cells were crystallized, MTT was removed, and DMSO was added to dissolve the metabolized MTT product. The absorbance was then measured on a Wallac Victor3 1420 multi-label counter at $540 \mathrm{~nm}$.
A

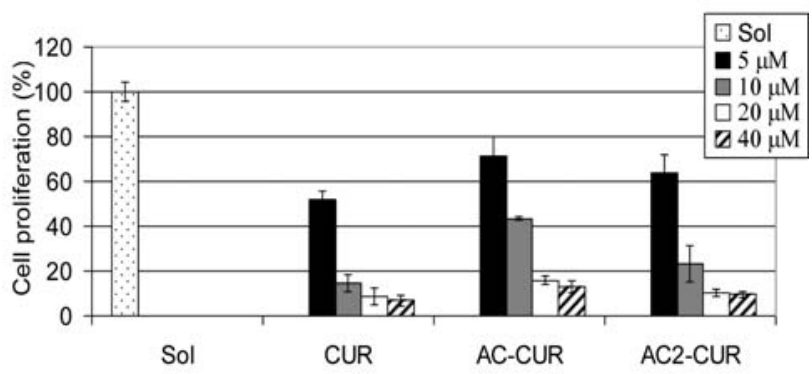

B

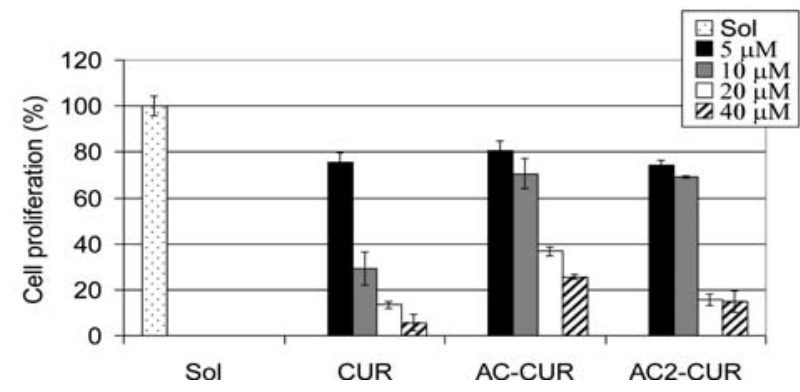

Figure 3. Cell proliferation-inhibitory effects of curcumin and its analogs on colon cancer cells. Human colon cancer cells HCT116 (A) and SW480 (B) were treated with the indicated concentrations of curcumin (CUR), curcumin monoacetate (AC-CUR) or curcumin diacetate (AC2-CUR) for $36 \mathrm{~h}$, followed by MTT assay.

\section{Results}

Curcumin acetates. Curcumin monoacetate $\mathbf{5}$ and curcumin diacetate 2 were prepared by a reported method (13) as shown in Fig. 1. Curcumin was acetylated by acetic anhydride in pyridine to provide the curcumin diacetate 2 . Selective protection of one phenol group by TBDMS gave the monoprotected compound $\mathbf{3}$. Acetylation of $\mathbf{3}$ with acetic anhydride in pyridine followed by removal of the TBDMS protecting group afforded curcumin monoacetate $\mathbf{5}$. The NMR spectra of the two compounds were consistent to that reported in the literature (13). We were able to obtain suitable crystals of curcumin diacetate for X-ray study, and its structure is shown in Fig. 2 (CCDC 746431 contains the supplementary crystallographic data for this study. These data can be obtained 
A

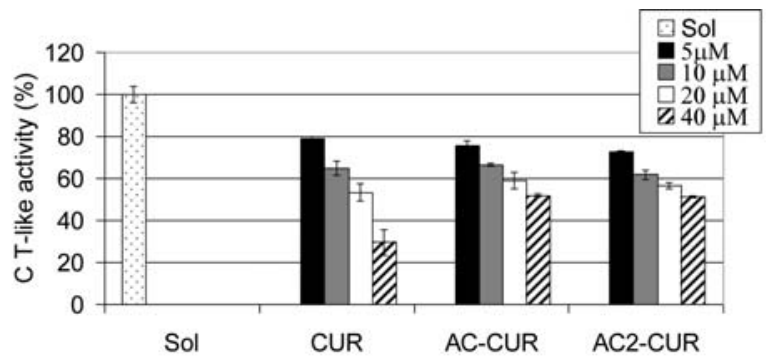

B

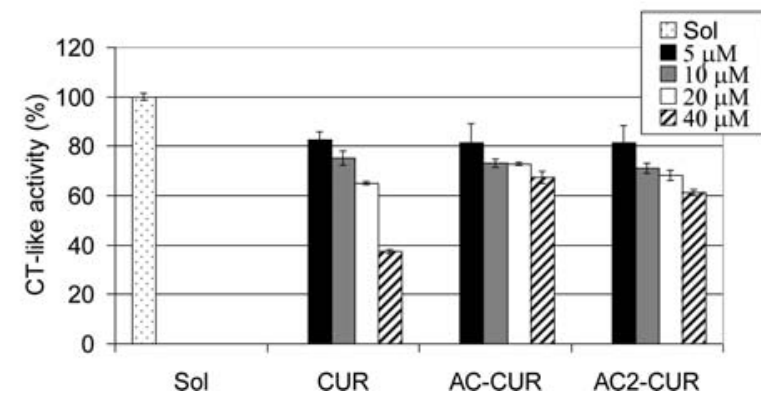

Figure 4. Proteasome-inhibitory effects of curcumin and its analogs on colon cancer cells. Human colon cancer cell lines HCT116 (A) and SW480 (B) were treated with the indicated concentrations of curcumin (CUR), curcumin monoacetate (AC-CUR) or curcumin diacetate (AC2-CUR) for $36 \mathrm{~h}$, followed by the proteasomal chymotrypsin (CT)-like activity assay.

from The Cambridge Crystallographic Data Centre, www. ccdc.cam.ac.uk/data_request/cif). As far as we are aware, no $\mathrm{X}$-ray structure determination of any curcumin derivative has been previously reported.

Bioassay of curcumin monoacetate and curcumin diacetate. Human colon cancer cells HCT116 and SW480 were treated with curcumin $\mathbf{1}$, curcumin monoacetate $\mathbf{5}$ and curcumin diacetate $\mathbf{2}$, and their cell proliferation inhibitory effects were examined (Fig. 3). At $20 \mu \mathrm{mol} / 1$ concentration, curcumin $\mathbf{1}$, curcumin monoacetate $\mathbf{5}$ and diacetate $\mathbf{2}$ all inhibited cell proliferation of HCT116 cells by $>80 \%$. At the same $20 \mu \mathrm{mol} / 1$ concentration, for human colon adenocarcinoma SW480 cells, curcumin $\mathbf{1}$ and curcumin diacetate $\mathbf{2}$ were equally effective in exhibiting a $>80 \%$ inhibition, with curcumin monoacetate $\mathbf{5}$ being somewhat less potent ( $>60 \%$ inhibition). The results suggest that acetylation of the hydroxyl groups does not significantly modify their activities against human colon cancer HCT 116 and SW480 cells relative to that of curcumin. The results corroborate a recent finding that dimethylcurcumin, with both hydroxyl phenolic groups methylated, has a similar antiproliferative activity in vitro in HCT116 cells as curcumin (14). On the other hand, the chymotrypsinlike proteasome inhibitory effects of curcumin monoacetate $\mathbf{5}$ and diacetate $\mathbf{2}$ were significantly lower than that of curcumin itself (Fig. 4). From the reported docking model of prediction of curcumin binding with the proteasome (8), one hydroxyl group of curcumin may have a hydrogen bond with the proteasome and this may have accounted for the difference.

Curcumin amino acid conjugates. Several amino acid conjugates of curcumin have been recently prepared, and their antiproliferative properties have been briefly studied without report of their effect on any molecular target (15). Since the proteasome has been identified as a potential target of curcumin, we aimed to assess whether the amino acid conjugates of curcumin have any inhibition activity on the proteasome. In the reported chemical synthesis, curcumin was reacted with the $N$-phthaloyl-amino acid chloride in pyridine, followed by removal of the phthaloyl protecting group by ammonia/pyridine, with a yield of $40-45 \%$ (16). We developed an alternative, more efficient method of preparation. Curcumin reacted with $N$-boc-glycine, $N$-boc-alanine, $N$-bocvaline, or $\mathrm{N}$-boc-glutamic acid 5-tert-butyl ester in anhydrous $\mathrm{CH}_{2} \mathrm{Cl}_{2}$, with EDCI and DMAP to provide the four protected amino acid bound curcumin $6,7,8$ and 9 as shown in Fig. 5 . The coupling also worked well when DCC was used as the coupling reagent, but the side product DCU was difficult to remove cleanly. Coupling of curcumin with $\mathrm{N}$-fmoc-glycine did not proceed with either EDCI or DCC. Deprotection of the $N$-boc group was carried out in TFA/anhydrous $\mathrm{CH}_{2} \mathrm{Cl}_{2}$ solution at $0^{\circ} \mathrm{C}$ for $4 \mathrm{~h}$, followed with $1 \mathrm{M}$ aq $\mathrm{HCl}$ in an ice bath. The solution was then concentrated under reduced pressure to give the hydrochloride salts in high overall yields. Bisglycinoylcurcumin dihydrochloride salt $\mathbf{1 0}$ was recrystallized in $\mathrm{MeOH} / \mathrm{CH}_{3} \mathrm{CN}$, whereas bisalaninoylcurcumin dihydrochloride salt $\mathbf{1 1}$ or bisvalinoylcurcumin<smiles>COc1cc(/C=C/C(=O)/C=C/c2ccc(O)c(OC)c2)ccc1O</smiles>

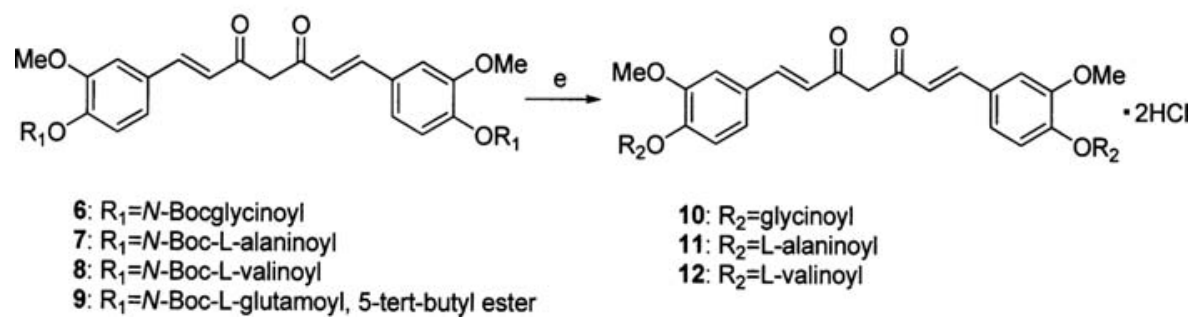




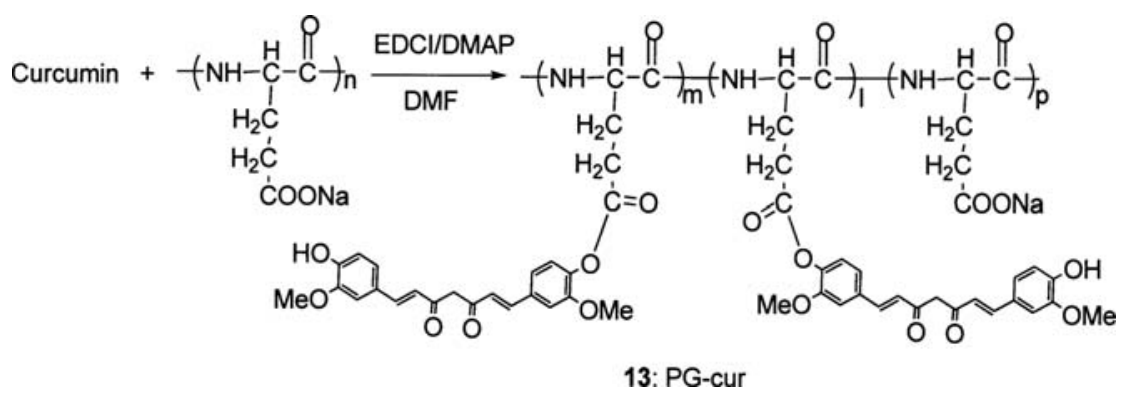

Figure 6. Synthesis of curcumin poly-L-glutamic acid conjugate $\mathbf{1 3}$.

A

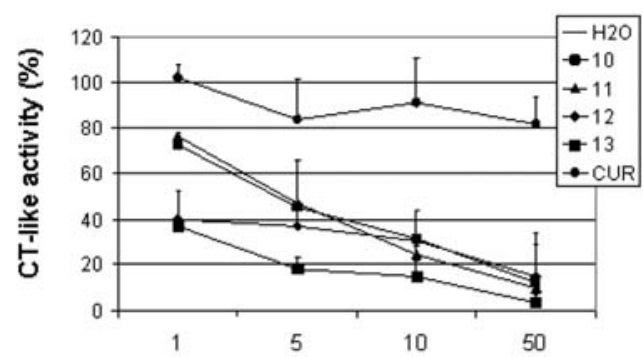

B

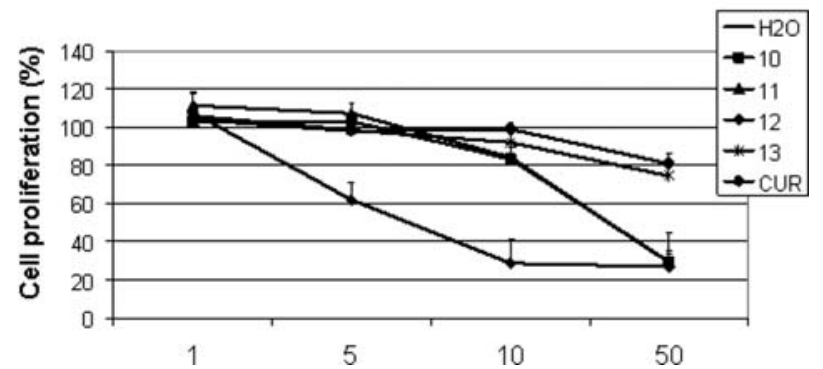

Figure 7. Inhibition on proteasome activity and cell proliferation by curcumin analogs. (A) The purified $20 \mathrm{~S}$ proteasome was incubated with the indicated concentrations of curcumin (CUR) or its analogs for $2 \mathrm{~h}$, followed by the proteasomal chymotrypsin-like activity assay. (B) $\mathrm{LNCaP}$ cells were treated with different concentrations of curcumin (CUR) or its analogs for $48 \mathrm{~h}$, followed by the MTT assay. All of the reagents were dissolved in water.

dihydrochloride salt 12 was recrystallized in $\mathrm{MeOH} / \mathrm{ether}$ or water, respectively. Deprotection of $\mathbf{9}$ under the same conditions did not give the pure bisglutamoylcurcumin, and we were not able to find an appropriate solvent mixture to recrystallize the crude bisglutamoylcurcumin. The $\mathrm{HCl}$ salts 10, 11 or 12 are all soluble in water.

With the availability of the EDCI coupling method, it was possible to couple curcumin to poly-L-glutamic acid (MW: 15000-50000). The poly-L-glutamic acid conjugate of curcumin $(\mathbf{1 3}$, PG-cur) was obtained according to Fig. 6 . The amount of curcumin in $\mathbf{1 3}$ was estimated to be $34 \% \mathrm{w} / \mathrm{w}$.

Bioassays of curcumin amino acid conjugates. The biological effects of curcumin were found to be limited in tissues remote from the gastrointestinal tract probably due to its poor water solubility and poor bioavailability. We compared curcumin in a water suspension with the aqueous solutions of its amino acid conjugated analogs $\mathbf{1 0 - 1 3}$ in terms of inhibition on the purified $20 \mathrm{~S}$ proteasome and tumor cell proliferation. As

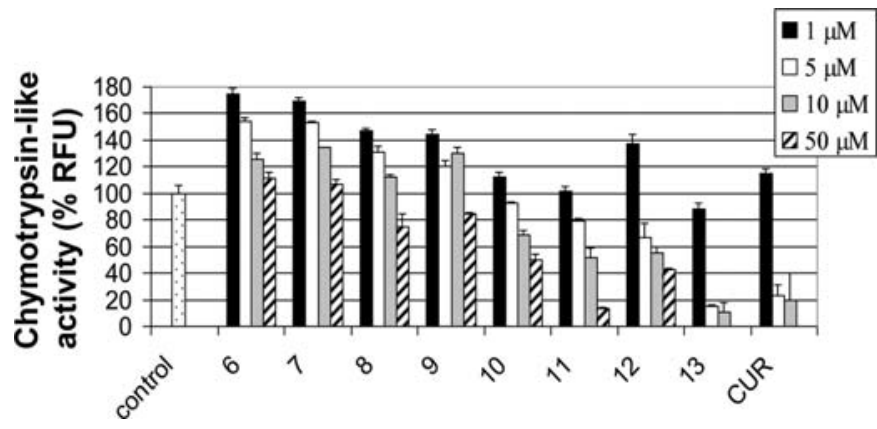

Figure 8 . Inhibition of purified 20 S proteasome activity by curcumin analogs. The 20S proteasome was incubated with indicated concentrations of curucmin (CUR), and its analogs were dissolved in different solvents (6-9 in DMSO; 10-12 in $\mathrm{H}_{2} \mathrm{O} ; 13$ and curcumin in ethanol) for $2 \mathrm{~h}$, followed by the chymotrypsin-like activity assay.

shown in Fig. 7A, an aqueous curcumin suspension induced $\sim 20 \%$ inhibition on the $20 \mathrm{~S}$ proteasome at 1-50 $\mu \mathrm{M}$. In sharp contrast, all of the conjugates in aqueous solution potently inhibited the $20 \mathrm{~S}$ proteasome. Among them, $\mathbf{1 3}$ was the most potent one, inducing $63-96 \%$ inhibition to the $20 \mathrm{~S}$ proteasome at $1-50 \mu \mathrm{M}$ (Fig. 7A). Next we examined the antiproliferative effects of compounds $\mathbf{1 0 - 1 3}$ against the prostate cancer cell line LNCaP. Compound $\mathbf{1 3}$ slightly inhibited cell growth in human prostate cancer LNCaP cells, similar to the parental compound curcumin. Compounds 10-12, on the other hand, potently inhibited cell growth, demonstrating 38-71\% inhibition by $\mathbf{1 2}$ at $5-10 \mu \mathrm{M}$ and $70 \%$ inhibition by $\mathbf{1 0}$ and $\mathbf{1 1}$ at $50 \mu \mathrm{M}$ (Fig. 7B).

To test whether water soluble curcumin amino acid conjugates 10-12 have comparative biological effects as curcumin in ethanol solution, we examined the chymotrypsin-like proteasome inhibitory effects of compounds 6-13 in comparison with curcumin by using water solutions of curcumin analogs 10-12 and DMSO solutions of curcumin analogs 6-9 and ethanol solutions of curcumin analog $\mathbf{1 3}$ as well as curcumin itself. As shown in Fig. 8, all of the bocprotected compounds 6-9 were essentially inactive in inhibiting the CT-like activity of purified proteasome in vitro, with $<20 \%$ inhibition at a $50 \mu \mathrm{mol} / 1$ concentration. In contrast, the amino acid conjugated curcumin analogs 10-13 were good inhibitors of the CT-like activity of the proteasome in a dose-dependent manner. In particular, compound $\mathbf{1 3}$ demonstrated potent inhibition. 
A

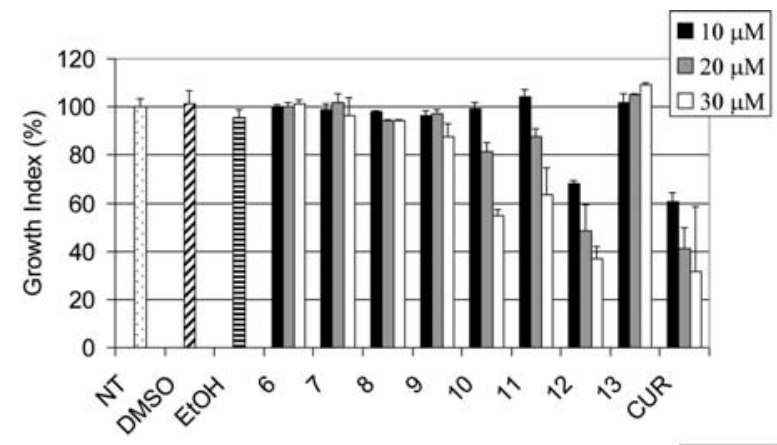

B

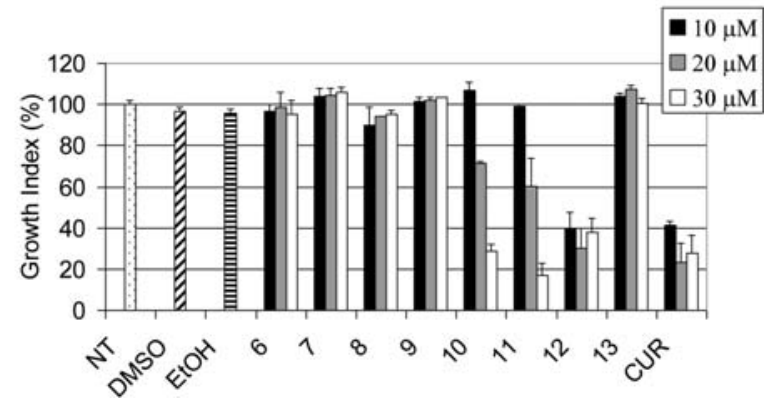

Figure 9. Inhibition of cell proliferation by curcumin analogs. PC-3 (A) or LNCaP (B) cells were treated with the indicated concentrations of curcumin (CUR) or its analogs which were disolved in DMSO or ehanol (EtOH) for $48 \mathrm{~h}$, followed by the MTT assay.

We then examined the antiproliferative effects of compounds 6-13 against the prostate cancer cell lines LNCaP and PC-3. MTT assays indicated that the amino acid conjugates 10, 11 and 12 were potent in inhibiting cell proliferation in both PC-3 (Fig. 9A) and LNCaP cells (Fig. 9B), similar to curcumin. The boc-protected compounds 6-9 were essentially
A

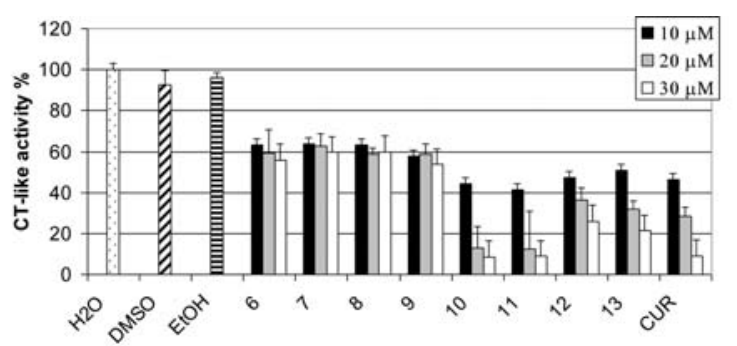

B

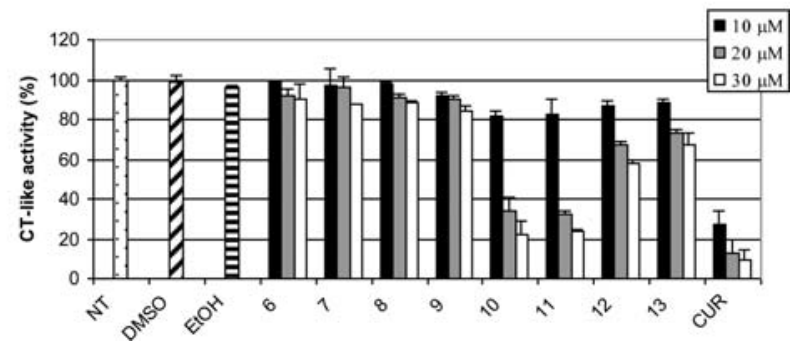

Figure 10. 26S proteasome inhibition by curcumin analogs. PC-3 (A) or $\mathrm{LNCaP}(\mathrm{B})$ cell extracts were incubated with the indicated concentrations of curcumin (CUR) or its analogs which were disolved in DMSO or ethanol (EtOH) for $2 \mathrm{~h}$, followed by the chymotrypsin-like activity assay.

inactive under these conditions. Notably, compound 13, which had the highest potency in the inhibition of purified proteasome (Fig. 8), was essentially inactive in the growth inhibition of either PC-3 or LNCaP cells.

The cancer cell growth inhibition activity of compounds 10-12 was possibly due to its ability to inhibit proteasome from the cells. By using the PC-3 cell extract, we demonstrated that the amino acid conjugates 10-12 were able to

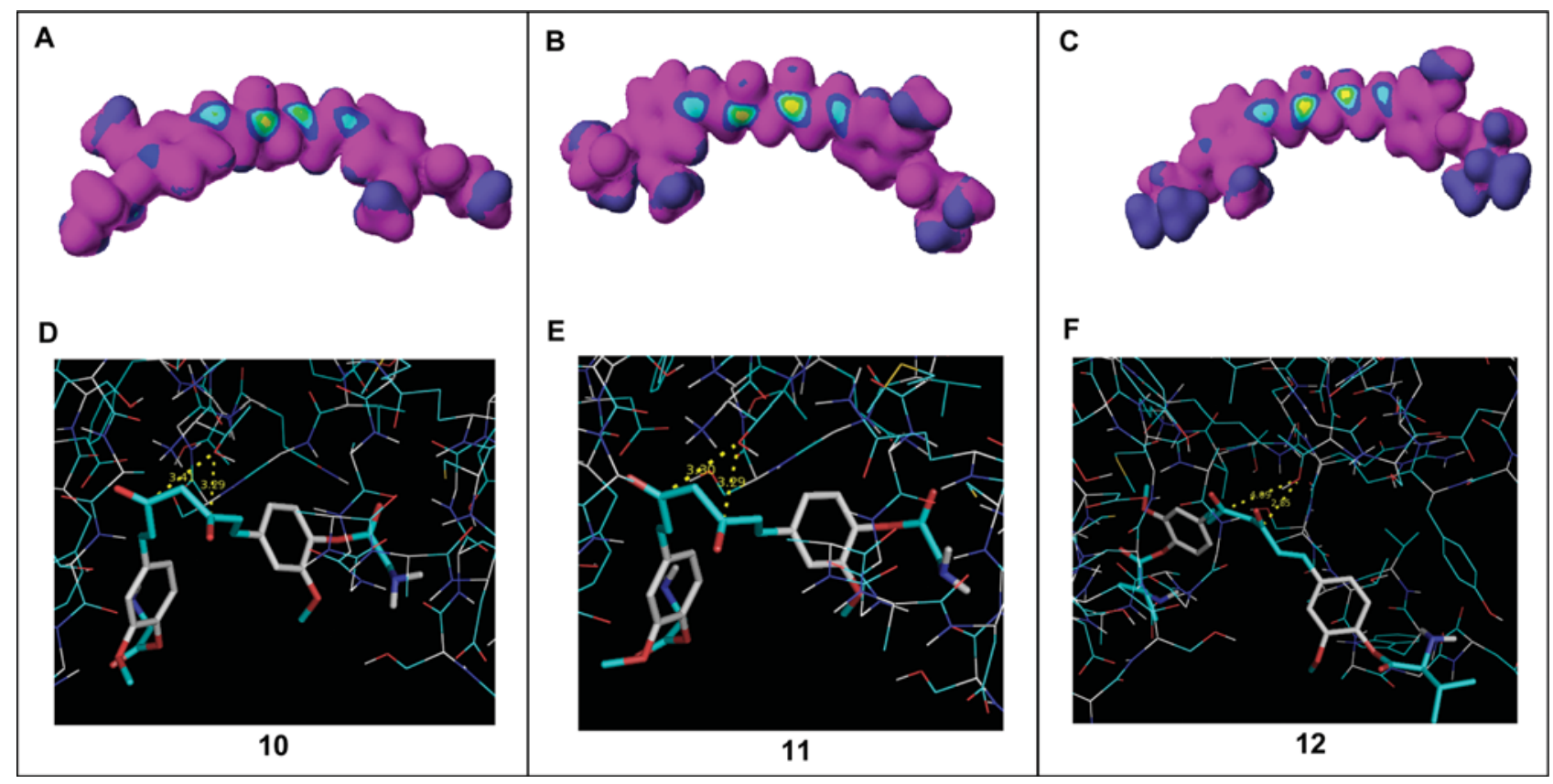

Figure 11. Computational docking analysis. (A-C) Electron density was analyzed in curcumin analogs $\mathbf{1 0}, \mathbf{1 1}$ and $\mathbf{1 2}$ using CaChe software. The bull's eyes with a yellow center indicated high nucleophilic susceptibility. (D-F) These compounds were docked into the $B 5$ subunit of the proteasome. The distances from the carbonyl carbons to the $\mathrm{OH}$ group of Thr1 of the 35 subunit were 3.29 or $3.41 \AA$ in compound $\mathbf{1 0}, 3.29$ or $3.30 \AA$ in compound $\mathbf{1 1}$ and 2.85 or $4.09 \AA$ in compound 12. Compounds $\mathbf{1 0 - 1 2}$ are shown as stick models. The $\mathrm{OH}$ group in Thr1 is shown in red and white. 
inhibit the chymotrypsin-like activity of the proteasome, comparable in potency as curcumin itself (Fig. 10A). Similarly, using the LNCaP cell extract, compounds 10-12 inhibited the chymotrypsin-like activities of the proteasome as well (Fig. 10B).

We noted that compound $\mathbf{1 3}$ was capable of inhibiting the $20 \mathrm{~S}$ and $26 \mathrm{~S}$ proteasome in vitro, but failed to inhibit cell growth in prostate cancer cells. A possible explanation is that compound 13 , because of its high molecular weight, was not absorbed by the cells.

Docking studies. For a better understanding of how the curcumin amino acid conjugates inhibit the 35 subunit of the proteasome, we first performed a computational structure analysis for analogs 10-12. The results revealed that carbonyl carbons are highly susceptible to nucleophilic attack forming a 'bull's eye' with a yellow center (Fig. 11A-C). We subsequently carried out molecular modeling to test whether these carbonyl carbons inhibit the proteasome. Preference was given to multiple clusters. In compound $\mathbf{1 0}$, one multiple cluster was obtained with 3 members (Fig. 11D). It was placed in a conformation where the carbonyl carbons were 3.29 or $3.41 \AA$ away from the N-terminal threonine (Thr 1) (Fig. 11D). The lowest docked energy was $-9.64 \mathrm{Kcal} / \mathrm{mol}$. In compound 11, one multiple cluster with 2 members was obtained (Fig. 11E). It was placed in a conformation where the carbonyl carbons were 3.29 or $3.30 \AA$ away from Thr 1 (Fig. 11E). The lowest docked energy was $-9.44 \mathrm{Kcal} / \mathrm{mol}$. Results obtained in compound 12, showing the docking pose most adopted by compound 12, places the carbonyl carbons 2.85 or $4.09 \AA$ distance from Thr 1, with a docked energy of $-6.19 \mathrm{Kcal} / \mathrm{mol}$ (Fig. 11F).

\section{Discussion}

There is considerable current interest in evaluating curcumin for the treatment of various types of cancers, including multiple myeloma, pancreatic cancer and colon cancer (2-4) since there is no apparent toxicity associated with curcumin even at very high doses (2-4). On the other hand, the effects of curcumin in other solid tumors have been modest, primarily due to its poor water solubility and poor bioavailability in tissues remote from the gastrointestinal tract (5). Recently, it has been suggested that curcumin inhibits the proteasome which may be the mechanism by which curcumin exerts its anticancer activity. Here, we studied the possibility of using simple conjugates of curcumin to ascertain whether its water solubility improves and its biological activities are enhanced. We prepared the monoacetate $\mathbf{5}$ and diacetate $\mathbf{2}$ of curcumin and found that they were not more potent than curcumin itself in terms of their cell proliferation inhibitory effects (Fig. 3). As inhibitors of the chymotrypsin-like activity of purified proteasome, the acetates were not as effective as curcumin (Fig. 4). Since the acetates are quite insoluble in water, they do not offer any apparent advantage over curcumin.

We next examined a number of amino acid conjugates of curcumin. The bis-glycinoylcurcumin dihydrochloride salt $\mathbf{1 0}$, bis-alaninoylcurcumin dihydrochloride salt $\mathbf{1 1}$ and bis-valinoylcurcumin dihydrochloride salt $\mathbf{1 2}$ are all soluble in water.
More importantly, aqueous solutions of these amino acid conjugates demonstrated a potent antiproliferative effect against the prostate cancer cell line LNCaP whereas an aqueous suspension of curcumin did not (Fig. 7B). The antiproliferative effect was presumably due to the inhibition of chymotrypsin-like activity of the proteasome by 10-12 (Fig. 7A). The biological activities of curcumin were restored only when it was dissolved in ethanol (Figs. 8, 9 and 10).

While compounds 10-12 may act as a prodrug of curcumin, this did not appear to be the reason for their activities as they are potent proteasome inhibitors in their own right (Figs. 7A and 10). Docking studies of these compounds show that they can bind to the same active site of the 35 subunit of the proteasome (Fig. 11). The binding places the carbonyl carbons of these compounds in proximity with the N-terminal threonine (Thr 1). Furthermore, calculation indicates that these carbonyl carbons are highly susceptible to nucleophilic attack (Fig. 11A-C). The computational studies are therefore consistent with the experimental results that compounds 1012 are potent proteasome inhibtors. The potent extracellular proteasome inhibition was also manifested in higher potency in cytotoxicity against LNCaP cells (Fig. 7B) than that of curcumin. These data suggest that compounds 10-12, when dissolved in aqueous solution, are readily absorbed by cancer cells. This is in contrast to compound $\mathbf{1 3}$ which was capable of inhibiting the 20S and 26S proteasome in vitro, but failed to inhibit cell growth in prostate cancer cells. The present results give encouragement to the possibility that water soluble amino acid conjugates of curcumin may be useful as chemotherapeutic or chemopreventive agents for cancer in place of curcumin. Validation of such a possibility using animal models is warranted.

\section{Acknowledgements}

We thank HKRGC (project no. 5003/05P), the Areas of Excellence Scheme established under the University Grants Committee of Hong Kong SAR, China (project no. AoE/P10/01), and the Niche Area funding scheme of the Hong Kong Polytechnic University for financial support. Funding from the Natural Sciences and Engineering Research Council of Canada (NSERC) and the National Cancer Institute (grant nos. 1R01CA120009 and 3R01CA120009-04S1) is gratefully acknowledged.

\section{References}

1. Ammon HPT and Wahl MA: Pharmacology of curcuma-longa. Planta Medica 57: 1-7, 1991.

2. Hatcher H, Planalp R, Cho J, Torti FM and Torti SV: Curcumin: from ancient medicine to current clinical trials. Cell Mol Life Sci 65: 1631-1652, 2008.

3. Aggarwal BB, Sundaram C, Malani N and Ichikawa H: Curcumin: the Indian solid gold. Adv Exp Med Biol 595: 1-75, 2007.

4. Landis-Piwowar KR, Milacic V, Chen D, Yang H, Zhao Y, Chan TH, Yan B and Dou QP: The proteasome as a potential target for novel anticancer drugs and chemosensitizers. Drug Resist Update 9: 263-273, 2006.

5. Garcea G, Jones DJ, Singh R, Dennison AR, Farmer PB, Sharma RA, Steward WP, Gescher AJ and Berry DP: Detection of curcumin and its metabolites in hepatic tissue and portal blood of patients following oral administration. Br J Cancer 90: 1011-1015, 2004. 
6. Ireson CR, Jones DJL, Orr S, et al: Metabolism of the cancer chemopreventive agent curcumin in human and rat intestine. Cancer Epidemiol Biomarkers Prev 97: 105-111, 2002.

7. Pan MH, Huang TM and Lin JK: Biotransformation of curcumin through reduction and glucuronidation in mice. Drug Metab Dispos 27: 486-494, 1999.

8. Yang H, Landis-Piwowar KR, Chen D, Milacic V and Dou QP: Natural compounds with proteasome inhibitory activity for cancer prevention and treatment. Curr Prot Peptide Sci 9: 227-239, 2008.

9. An B, Goldfarb RH, Siman R and Dou QP: Novel dipeptidyl proteasome inhibitors overcome $\mathrm{Bcl}-2$ protective function and selectively accumulate the cyclin-dependent kinase inhibitor p27 and induce apoptosis in transformed, but not normal, human fibroblasts. Cell Death Differ 5: 1062-1075, 1998.

10. Jagannath S, Barlogie B, Berenson J, et al: A phase 2 study of two doses of bortezomib in relapsed or refractory myeloma. Br J Haematol 127: 165-172, 2004.

11. Lam WH, Kazi A, Kuhn DJ, Chow LMC, Chan ASC, Dou QP and Chan TH: A potential prodrug for a green tea polyphenol proteasome inhibitor: evaluation of the peracetate ester of (-)epigallocatechin gallate [(-)-EGCG]. Bioorg Med Chem 12: 5587-5593, 2004.
12. Li C, Price JE, Milas L, Hunter NR, Ke S, Yu D, Charnsangavej C and Wallace S: Antitumor activity of poly(L-glutamic acid)paclitaxel on syngeneic and xenografted tumors. Clin Cancer Res 5: 891-897, 1999

13. Takeuchi T, Ishidoh T, Ijima H, et al: Structural relationship of curcumin derivatives binding to the BRCT domain of human DNA polymerase lambda. Genes Cell 11: 223-235, 2006.

14. Tomovakopoulous C, Dimas K, Sofianos ZD, et al: Metabolism and anticancer activity of the curcumin analogue, dimethoxycurcumin. Clin Cancer Res 13: 1269-1277, 2007.

15. Dubey SK, Sharma AK, Narain U, Misra K and Pati U: Design, synthesis and characterization of some bioactive conjugates of curcumin with glycine, glutamic acid, valine and demethylenated piperic acid and study of their antimicrobial and antiproliferative properties. Eur J Med Chem 43: 1837-1846, 2008. 